\title{
DEVELOPMENT MECHANISM OF MINING-INDUCED GROUND FISSURE FOR SHALLOW BURIAL COAL SEAM IN THE MOUNTAINOUS AREA OF SOUTHWESTERN CHINA: A CASE STUDY
}

\author{
Hengzhong $\mathrm{ZHU}^{1,2)} *$, Fulian $\mathrm{HE}^{1,2)}$ and Yuqing FAN ${ }^{3)}$ \\ ${ }^{1)}$ School of Resources and Safety Engineering, China University of Mining and Technology (Beijing), Beijing 100083, China \\ ${ }^{2}$ Beijing Key Laboratory for Precise Mining of Intergrown Energy and Resources, China University of Mining and Technology (Beijing), \\ Beijing 100083, China \\ 3) School of Mining Engineering, Guizhou University of Engineering Science, Bijie, Guizhou 551700, China
}

*Corresponding author's e-mail: z_hz99@163.com

\begin{tabular}{l}
\hline ARTICLE INFO \\
\hline Article history: \\
Received 13 July 2018 \\
Accepted 14 November 2018 \\
Available online 20 November 2018 \\
\hline
\end{tabular}

\section{Keywords:}

Development regularity

Formation mechanism

Sliding-type ground fissure

Stepped-type ground fissure

Horizontal tensile deformation

Main roof movement mode

\begin{abstract}
Mining-induced ground fissure (MIGF) contributes to vegetation deterioration, landslides and other natural hazards. The study is an attempt to reveal the development type, dynamic development process, and formation mechanism of MIGF for MIGF-induced natural hazard prevention of shallow burial coal seam mining. A novel approach including in situ measurement, theoretical analysis, and numerical simulation was implemented. There are two typical types of fissures, namely sliding-type ground fissures and stepped-type ground fissures. Sliding-type ground fissures generally develop in a mountainous slope with a large gradient while steppedtype ground fissures typically occur in a mountainous slope with a small gradient and especially near a valley. Dynamic development process of MIGF is significantly affected by roof periodic movement. The advancing distance of a sliding-type ground fissure is 1.35 times periodic weighting step distance while it corresponds to 0.89 times the periodic weighting step distance for a stepped-type ground fissure. A positive relationship exists between horizontal tensile deformation and MIGF width. The movement mode of "voussoir beam" is favorable for slidingtype ground fissure development while the movement mode of "stepped beam" leads to steppedtype ground fissure development. These results can contribute to MIGF treatment and ecological protection in the southwestern mountainous area.
\end{abstract}

\section{INTRODUCTION}

With rapid and sustainable development of China's economy, China is already one of the countries with the highest energy consumption that mainly depends on coal resources across the world. Based on "The $13^{\text {th }}$ Five-Years Plan for Economic and Social Development of China (2016-2020)," the overall arrangement strategy for coal exploitation of "restricting central area and northeastern area, reducing eastern region and optimizing western area" is implemented (Commission, 2016). Western coal production accounts for more than $45 \%$ of the total in 2020 (Zhu et al,. 2017). Several large-scale coal production bases including Shanbei, Shendong, Ningdong, Xinjiang, and Yungui lie in the western area of China. The Yungui coal production base is known as "Southwestern Coal Sea" due to its abundant coal resources. Shallow burial coal seams with a burial depth less than $200 \mathrm{~m}$ occur in the western area with a proportion of more than $30 \%$ of the total proved reserves. In China, the shallow burial coal seam mining area is divided into two sections, namely the northwestern section and southwestern section. With respect to the southwestern mining area, the landform mainly consists of mountains with steep topography due to its special geographical location, (Liu et al., 2012; Bell and Genske, 2001; Zhu et al., 2017). Field observations indicate that mininginduced ground fissure (MIGF) occur in the mountainous surface during the process of coal exploitation. Indirectly, MIGF can cause water and soil loss, vegetation deterioration, landslide, building destruction, and other natural hazards (Adibee et al., 2013; Huang et al., 2014; Malinowska, 2016; Marschalko et al., 2012). Several landslides including Dashujiao, Bide, and Yingping occurred by the end of 2017. The MIGF of Pusa colliery led to the Dajiaoshu landslide with seventeen fatalities and eighteen missing individuals.

It is clarified that MIGF is an important cause of landslides (Tang, 1989; Zhang et al., 2015) and that the continuous development of MIGF significantly affects mountain slope stability. This coupled with the infiltration of rainfall and surface water can lead to mining-induced landslides along the weak structural surface. The formation mechanism of MIGF depends on a series of factors such as overlying strata movement mode, surface soil layer characteristic, surface topography, burial depth, mining height, mining method, gob dimensions, and advancing 
speed. Several studies indicated factors that clarify MIGF including theoretical analysis, numerical simulation and field investigation (Liu et al., 2016; Qiao, 2000; Xu et al., 2017; Zhao et al., 2016). The studies include development regularity, formation mechanism, and prediction method (Fan et al., 2015; $\mathrm{Hu}$ et al., 2014; $\mathrm{Xu}$ et al., 2015), but they are mainly focus on MIGF of the northwestern section. With respect to typical examples, Hui Liu clarified the development regularity of MIGF by focusing on northwestern loess gully area and proposed corresponding treatment approach (Liu et al., 2017). Jianwei Li proposed a novel approach including in situ measurement, theoretical analysis, and numerical simulation to examine the formation mechanism and development regularity of MIGF for the northwestern shallow thick coal seam mining area ( $\mathrm{Li}$ and Liu, 2017). Kuifeng Han proposed a method to forecast the development position of MIGF based on surface subsidence characteristic (Han et al., 2014).

Thick loose layer and thin bedrock are two typical characteristics of shallow burial coal seam occurrence condition for northwestern section (Zhu et al,. 2018). Different from the northwestern section, complex topography, thin loose layer and thick bedrock are typical occurrence conditions for coal seam in the southwestern section. It is known that overlying strata movement mode is affected by the occurrence condition of coal seam. In essence, MIGF is a coupled result of overlying strata movement and surface subsidence. It is important to investigate whether the development regularity of MIGF is different under different two occurrence conditions and to examine the formation mechanism of MIGF for southwestern section. The aforementioned issues should be urgently addressed. Therefore, it is extremely important to explore the overlying strata movement mode and surface subsidence characteristic to investigate the developmental regularity and formation mechanism of MIGF. However, most studies mainly focus on the northwestern section, and there is a paucity of studies on the southwestern section. Hence, it is important to examine the development regularity and formation mechanism of MIGF; and it is of practical significance in protecting ecological environment and preventing natural hazards.

The study considers Anshun colliery in Guizhou Province of southwestern China as a typical case study and describes the development regularity and formation mechanism of MIGF focusing on the southwestern section. The development characterristics, development form, and distributive region of MIGF are explained through in situ measurements. Furthermore, the relationship between dynamic development process of MIGF and working face advancing progress is also clarified. Finally, we also examined the formation mechanism of MIGF from two viewpoints of overlying strata movement and surface subsidence.

\section{CASE STUDY}

\subsection{MINING AND GEOLOGICAL CONDITION}

The typical case study aims at Anshun colliery; it is located in Anshun City, Guizhou Province, southwestern China, covers a mining area of $22 \mathrm{~km}^{2}$ (Fig. 1). The coal bearing strata belong to the Longtan Foramtion, upper Permian. M8 and M9 are two minable coal seams with the thickness of $1.65 \mathrm{~m}$ and $2.87 \mathrm{~m}$, respectively. The average space between M8 and M9 is $18 \mathrm{~m}$, it belong to close-space multi-seam mining. This study was implemented in a typical area: 9100 working face with the striking length of $896 \mathrm{~m}$ and the inclination length of $190 \mathrm{~m}$. The ground surface of the mining area mainly consists of mountains. The maximum and minimum burial depths are $217.5 \mathrm{~m}$ and $106.3 \mathrm{~m}$, respectively, and the maximum altitude difference is nearly $128 \mathrm{~m}$. The 9100 working face adopts the long wall mining method. It is mined with a mining height of $2 \mathrm{~m}$ and a mining speed of $3 \mathrm{~m} / \mathrm{d}$. The geological survey was conducted along the section line of A-B by using GPS. Based on the geological survey results, the ground surface of the 9100 working face is mainly mountains with a maximum slope gradient of $54.7^{\circ}$ and an average slope gradient of $26.6^{\circ}$ (Fig. 1). The peak point corresponds to Denglongshan mountain with a maximum altitude of $1657 \mathrm{~m}$ while the lowest point corresponds to Moshi River with a minimum altitude of $1460 \mathrm{~m}$. In the process of coal exploitation, several MIGFs are generated in the ground surface and resulting in cracks in the surface soil layer. When MIGF connects with the gob, it directly threats mining safety. Furthermore, a landslide had occurred. To protect ecological environment and prevent natural hazard, a large program of in situ measurement for MIGF was conducted.

\subsection{IN SITU MEASUREMENT}

A relatively large program was conducted to determine characteristic of MIGF in the 9100 working face. Eight monitoring lines were arranged along the inclination direction of the 9100 working face, and a monitoring line was placed every 100 meters, as shown in Figure 2. The X91 (Globe positioning system) GPS-(Real-time kinematic) RTK receiver is used to orientate the position of MIGF, and the width and fall of MIGF is determined by using the measuring tape. A monitoring line of A-B along the striking direction was arranged to observe the surface subsidence, and thirty monitoring points were placed every 30 meters with serial number of Z1-Z31. With respect to mining pressure measurement, an observation work was conducted in the region varies from $485 \mathrm{~m}$ to $600 \mathrm{~m}$ along the striking direction.

\section{RESULTS AND DISCUSSION \\ 3.1. DEVELOPMENT TYPE OF MIGF}

Following the Global positioning system (GPS) measurement standard GB/T 18314-2009 and Global 

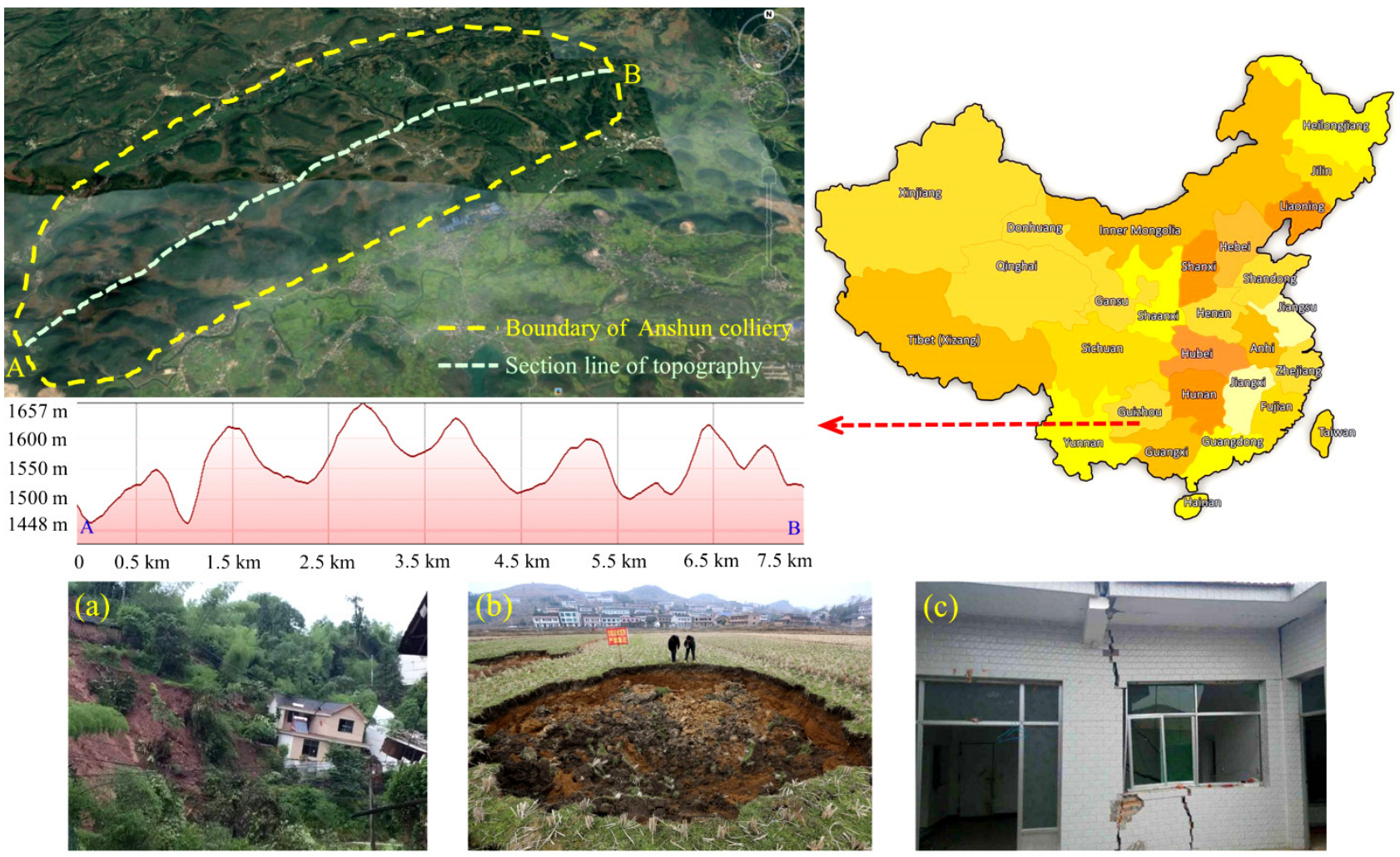

Fig. 1 Mining-induced natural hazards: (a) landslide, (b) surface sinkhole and (c) fissures in buildings.

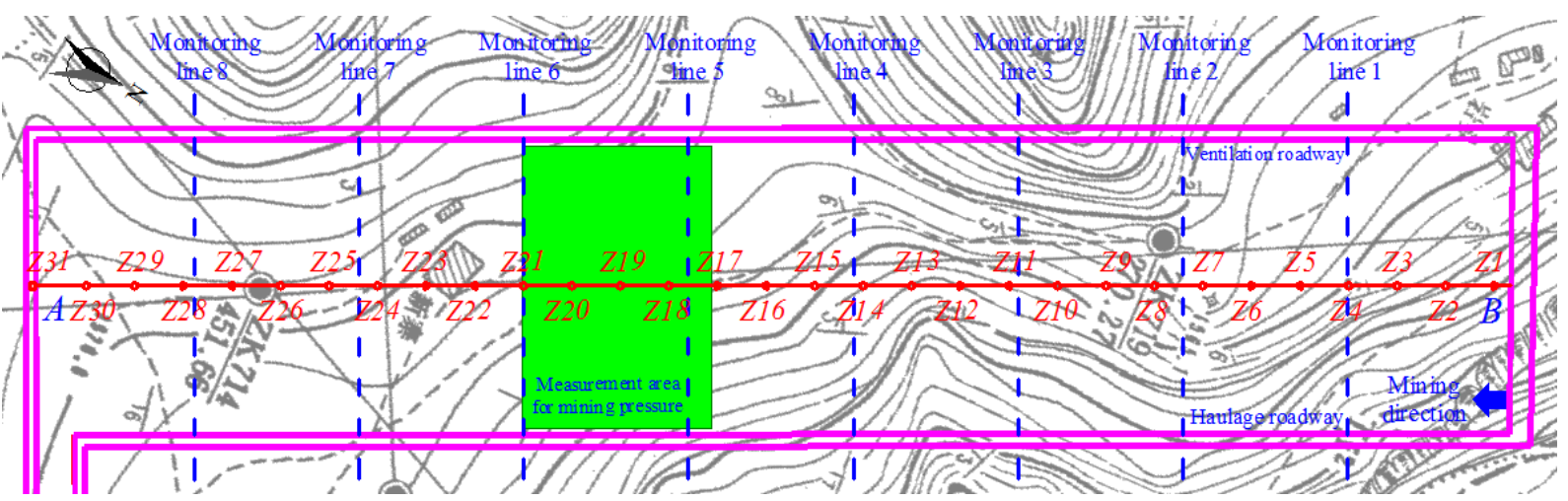

Fig. 2 In situ measurement for MIGF, surface subsidence and mining pressure.

positioning system real-time dynamic measurement (RTK) technical standard CH/T 2009-2010, the position of MIGF was determined on the ground surface of the 9100 working face. As for the accuracy of the GPS measurement, the plane accuracy is $\pm\left(8+1 \times 10^{-6} \times \mathrm{D}\right) \mathrm{mm}$ while the leveling accuracy is $\pm\left(15+1 \times 10^{-6} \times \mathrm{D}\right) \mathrm{mm}$, where the $\mathrm{D}$ is the square diameter when taking the GPS as the center. The MIGF is divided into two typical types, namely sliding-type ground fissures and stepped-type ground fissures based on analysis result of monitoring data.

Sliding-type ground fissures typically develop in a mountainous slope and especially on hillsides with large gradient. It exhibits relative high width, fall, and fissure angle. Based on measurement data of eleven sliding-type ground fissures, the maximum width, fall, and fissure angle are $1.05 \mathrm{~m}, 1.42 \mathrm{~m}$, and $82.1^{\circ}$, respectively. The development morphology of sliding- type ground fissure exhibits a curved shape, and its extension direction typically runs parallel to the acting orientation of compressive stress or perpendicular to the acting orientation of tensile stress. Under the influence of mining activity, the overlying strata and surface soil layer moves in different degrees. Thus, a non-synchronous slippage exists towards the downslope direction. Sliding-type ground fissure is the coupled result of the two factors including mountainous slope subsidence and the horizontal tensile displacement of surface soil layer. It significantly affects the mountainous slope stability. It directly threatens mining safety especially while connecting with the gob.

Stepped-type ground fissures generally develop in a mountainous slope with a small gradient and especially in slopes that are near a valley. In situ observation suggests that a stepped-type ground 


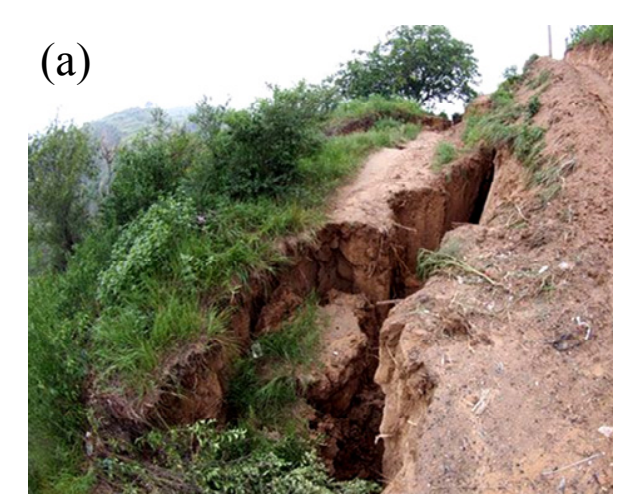

Fig. 3 Two typical types of MIGF: (b) stepped-type ground fissure.

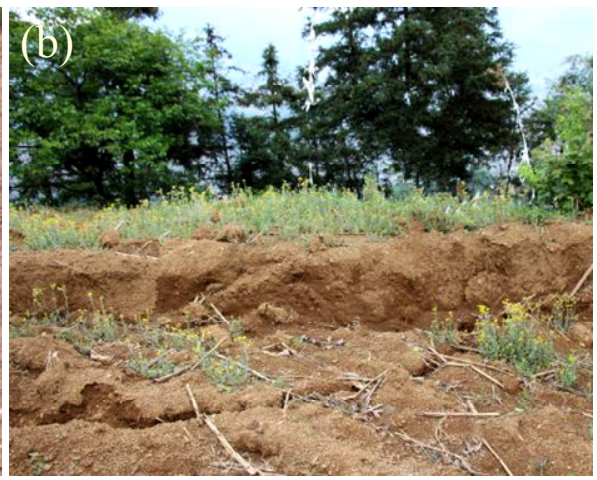

(a) sliding-type ground fissure and

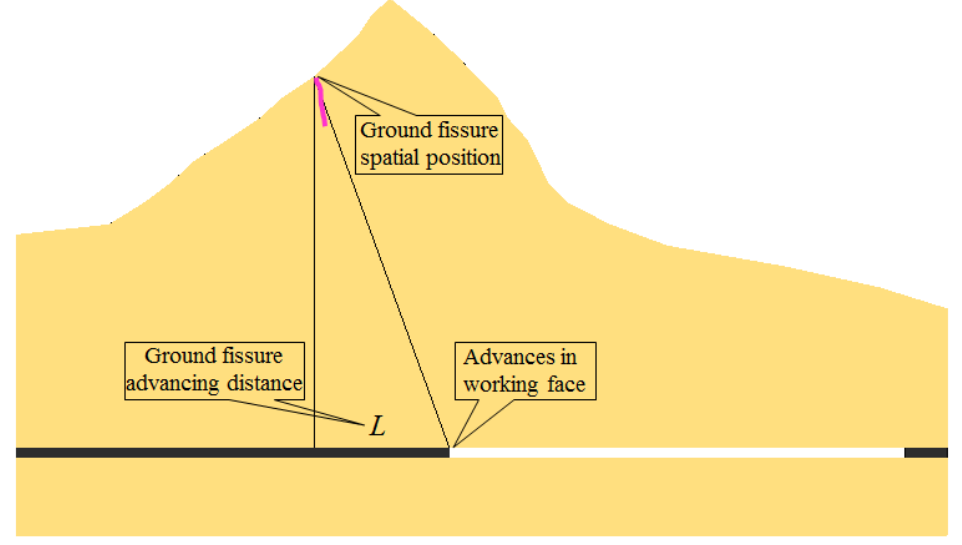

Fig. 4 The diagrammatic sketch of ground fissure advancing distance.

fissure exhibits a stepped-shape and that it exhibits low width and fall. The average width is $0.14 \mathrm{~m}$ while the average fall is $0.39 \mathrm{~m}$. Stepped-type ground fissures close after surface subsidence tends towards stability. The development morphology of steppedtype ground fissure exhibits the shape of a straight line, and it is typically parallel to the working face advancing orientation. Stepped-type ground fissures significantly affect farmland and surface vegetation

\subsection{DYNAMIC DEVELOPMENT REGULARITY OF MIGF}

A large amount of measurement data was collected to determine the development regularity of MIGF. We describe dynamic development regularity of sliding-type ground fissure and stepped-type ground fissure as the working face advances in this section. The relationship between dynamic development regularity and periodic weighting step was concretely elaborated. Furthermore, the development cycle of the two kinds of ground fissures was also examined.

\subsubsection{DYNAMIC DEVELOPMENT REGULARITY OF SLIDING-TYPE GROUND FISSURE}

It is revealed that a close relationship exists between development regularity of MIGF and mining activity. In order to better clarify the relationship, a comprehensive observation method based on the united coordinate control system of surfaceunderground was adopted to monitor dynamic development regularity of MIGF with the advance of working face. The observation region varies from $0 \mathrm{~m}$ to $450 \mathrm{~m}$ along the striking direction of the 9100 working face.

The relationship between the development spatial position of six sliding-type ground fissures and working face advancing progress is shown in Table 1. The ground fissure advancing distance $L$ is the distance between advancing position of working face and the ground fissure occurrence position (Fig. 4). It is observed that sliding-type ground fissure advancing distance ranges from $19.3 \mathrm{~m}$ to $43.8 \mathrm{~m}$ with an average value of $29.8 \mathrm{~m}$. Based on the monitoring results of roof movement regularity, the periodic weighting step distance is 19.3-23.1 $\mathrm{m}$ with an average distance of $22.1 \mathrm{~m}$. It is concluded that sliding-type ground fissure advancing distance is approximately 1-2 times the periodic weighting step distance. When combined with the geological survey result of slope gradient and coal seam burial depth, the interval distance between sliding-type ground fissures generally increases with increases in the slope gradient and coal seam burial depth. Additionally, the sliding-type ground fissure first develops in the middle of working face and then extends to the two flanks of the working face. This discovery is consistent with the results in a previous study $(\mathrm{Li}$, 
Table 1 Relationship between the sliding-type ground fissure spatial position and working face advancing progress.

\begin{tabular}{ccccc}
\hline $\begin{array}{c}\text { Observation } \\
\text { time }\end{array}$ & $\begin{array}{c}\text { Advances in } \\
\text { working face } \\
(\mathrm{m})\end{array}$ & $\begin{array}{c}\text { Advancing distance } \\
\text { in working face } \\
(\mathrm{m})\end{array}$ & $\begin{array}{c}\text { Ground fissure } \\
\text { spatial position } \\
(\mathrm{m})\end{array}$ & $\begin{array}{c}\text { Ground fissure } \\
\text { advancing distance } \\
(\mathrm{m})\end{array}$ \\
\hline 2015.6 .3 & 160 & & 183.2 & 23.2 \\
2015.6 .10 & 181.5 & 21.5 & 211.8 & 30.3 \\
2015.6 .17 & 202.8 & 21.3 & 246.6 & 43.8 \\
2015.7 .8 & 264.4 & 61.6 & 283.7 & 19.3 \\
2015.7 .25 & 314.3 & 49.9 & 340.2 & 25.9 \\
2015.8 .2 & 335.3 & 21 & 372 & 36.7 \\
\hline
\end{tabular}

(a)

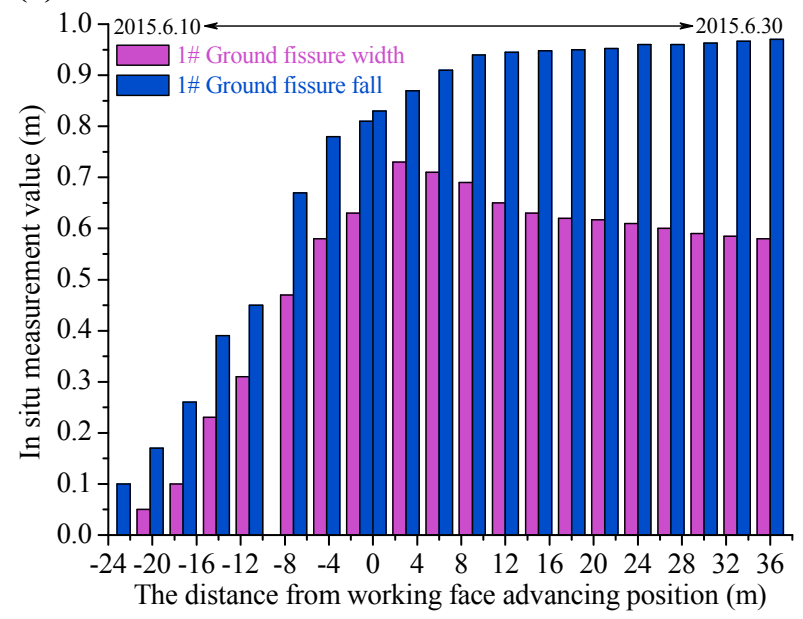

(b)

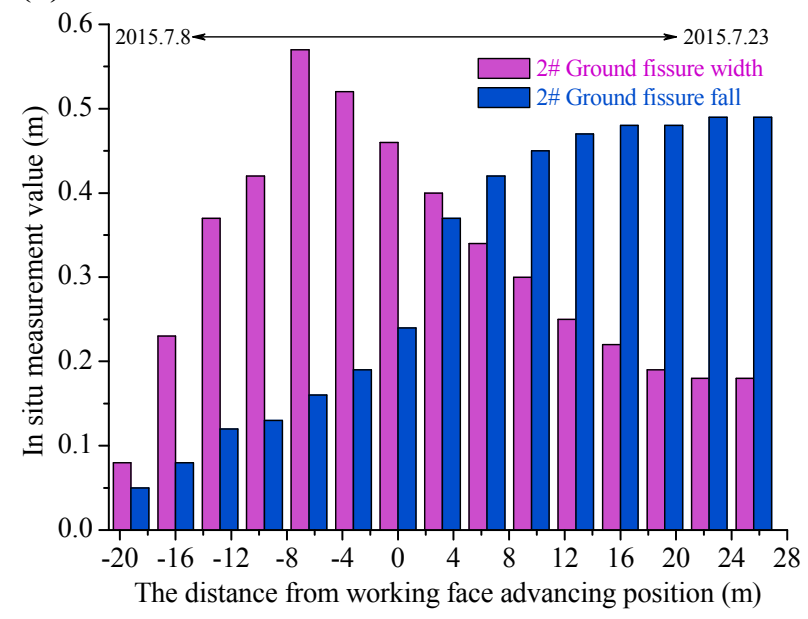

(c)

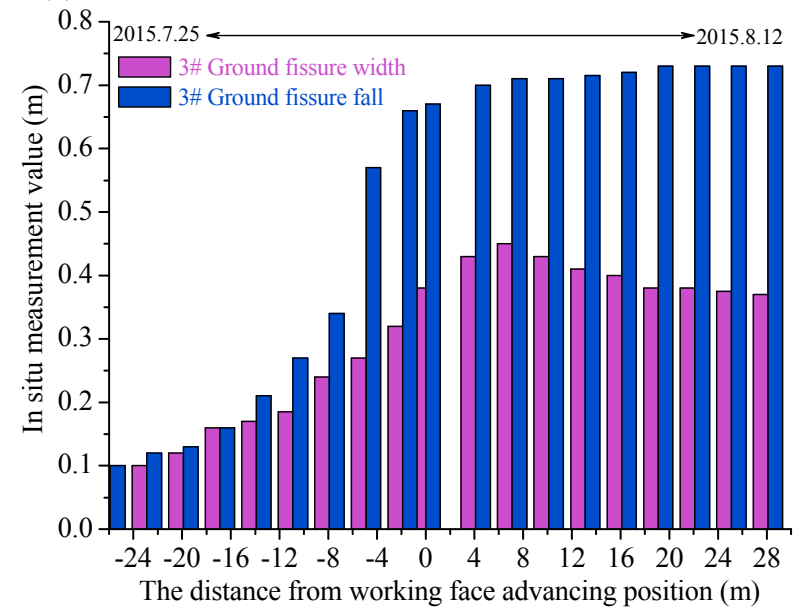

Fig. 5 Dynamic development of the width and the fall for (a) 1\# sliding-type ground fissure, (b) 2\# sliding-type ground fissure and (c) 3\# sliding-type ground fissure (Note: the distance value is negative when ground fissure is ahead of the working face while it is positive when it falls behind the working face).

2017). Moreover, the extension direction of slidingtype ground fissure is mainly parallel to the contour line orientation of topography.

Traditional views indicate that ground fissure development process is divided into four stages as follows: the deformation accumulation stage before ground fissure generation, ground fissure generation stage, expansion stage after ground fissure formation, and ground fissure closure stage after mining activity termination (Shi et al., 2016). Generally, ground fissures continuously expand when the working face advances and then gradually close after surface subsidence tends towards stability. The development stage of ground fissure width generally shows a single cycle that ranges from small to large and finally closes (Li et al., 2017). However, sliding-type ground fissure is a type of permanent ground fissure. Thus, the width of sliding-type ground fissure increases from small to large and finally tends towards a stable value. 
Table 2 In situ measurement result of stepped-type ground fissure.

\begin{tabular}{cccccc}
\hline Ground fissure & Width $(\mathrm{m})$ & Fall $(\mathrm{m})$ & Ground fissure & Width $(\mathrm{m})$ & Fall $(\mathrm{m})$ \\
\hline ST1 & 0.11 & 0.25 & ST9 & 0.06 & 0.62 \\
ST2 & 0.13 & 0.34 & ST10 & 0.13 & 0.46 \\
ST3 & 0.17 & 0.61 & ST11 & 0.18 & 0.65 \\
ST4 & 0.14 & 0.74 & ST12 & 0.15 & 0.56 \\
ST5 & 0.04 & 0.59 & ST13 & 0.17 & 0.68 \\
ST6 & 0.08 & 0.42 & ST14 & 0.09 & 0.43 \\
ST7 & 0.14 & 0.53 & ST15 & 0.16 & 0.72 \\
ST8 & 0.11 & 0.39 & ST16 & 0.55 \\
\hline
\end{tabular}

The situ measurement result of the width and fall of three typical sliding-type ground fissures are shown in Figure 5. It is observed that development regularity of three sliding-type ground fissures exhibit a similar characteristic. The stable value of width varies from $0.17 \mathrm{~m}$ to $0.58 \mathrm{~m}$ while the stable value of fall is $0.73-$ $0.97 \mathrm{~m}$. With advances in the working face, the width exhibits a development regularity that ranges from small to large, and then decreases towards a stable value after it obtains a maximum value. The initial value of the width is $0.01 \mathrm{~m}, 0.08 \mathrm{~m}$ and $0.05 \mathrm{~m}$ when the distance that is relative to the working face is $-23.2 \mathrm{~m},-19.2 \mathrm{~m}$ and $-25.9 \mathrm{~m}$, respectively. As the working face advances, the width increases gradually. When the distance that is relative to the working face is $3 \mathrm{~m},-6.4 \mathrm{~m}$ and $7.1 \mathrm{~m}$, the width achieves a maximum value of $0.73 \mathrm{~m}, 0.57 \mathrm{~m}$ and $0.45 \mathrm{~m}$. Afterwards, the width decreases gradually and then obtains a stable value of $0.58 \mathrm{~m}, 0.18 \mathrm{~m}$ and $0.37 \mathrm{~m}$ when the distance that is relative to the working face is $36 \mathrm{~m}, 25.6 \mathrm{~m}$ and $28.1 \mathrm{~m}$. With respect to the fall, it exhibits a development regularity that ranges from small to large and finally towards a stable value. The initial value of the fall is $0.1 \mathrm{~m}, 0.05 \mathrm{~m}$ and $0.1 \mathrm{~m}$. With the advances in the working face, when the distance that is relative to the working face is $-7.2 \mathrm{~m}$, $3.2 \mathrm{~m}$ and $-4.9 \mathrm{~m}$, the fall increases suddenly. Afterwards, the fall increases gradually and then obtains a stable value. The stable fall is $0.96 \mathrm{~m}$, $0.48 \mathrm{~m}$ and $0.73 \mathrm{~m}$, respectively, when the lagging distances of sliding-type ground fissure are $24 \mathrm{~m}$, $16 \mathrm{~m}$, and $19.1 \mathrm{~m}$, respectively. It is evident that the working face advancing position has an important influence on the development law of the width and the fall. With respect to the development cycle of the three sliding-type ground fissure, it corresponds to $21 \mathrm{~d}, 15 \mathrm{~d}$ and $19 \mathrm{~d}$ with an average time of $18.3 \mathrm{~d}$. The working face advancing distance is $54.9 \mathrm{~m}$ within the time of $18.3 \mathrm{~d}$. The distance is equivalent to 2.48 times the periodic weighting step distance.

\subsubsection{DYNAMIC DEVELOPMENT REGULARITY OF STEPPED-TYPE GROUND FISSURE}

In order to determine dynamic development regularity of stepped-type ground fissure, in situ measurement was conducted by using X91 GPS-RTK receiver and steel ruler. The measurement result for the width and the fall of sixteen stepped-type ground fissures were collected for the purpose of analyzing their development regularity (Table 2 ). The width is $0.04-0.18 \mathrm{~m}$ with an average value of $0.12 \mathrm{~m}$ while the fall is $0.25-0.74 \mathrm{~m}$ with an average value of $0.53 \mathrm{~m}$. This is different from sliding-type ground fissure, and the width of stepped-type ground fissure is smaller. With respect to the development shape, it typically exhibits an evident vertical staggered surface. Stepped-type ground fissure often develops with advances in the working face. Its development spatial position typically falls a certain distance behind the advances in the working face.

In order to better clarify the development regularity of stepped-type ground fissure, a relatively large comprehensive observation work was implemented to monitor its development process with the advances in the working face. An in situ observation was conducted in the region varying $390 \mathrm{~m}$ to $790 \mathrm{~m}$ of the 9100 working face. The relationship between the development of the spatial position of seven stepped-type ground fissures and the advances in the working face is shown in Table 3. Advances in the distance of stepped-type ground fissure vary from $16.7 \mathrm{~m}$ to $24 \mathrm{~m}$ with an average value of $19.7 \mathrm{~m}$. When compared with the periodic weighting step distance of $22.1 \mathrm{~m}$, the advancing distance is approximately the periodic weighting step distance. It is concluded that dynamic development regularity of stepped-type ground fissure is closely related to the periodic movement of overlying strata. After investigating the development position of stepped-type ground fissure, it is generally generated in the mountainous slope with a small gradient and especially in the slope that is near the valley. When the working face advances to the region (the topography of the region is the valley), the slippage of mountainous slope easily occurs under the influence of mining activity.

The in situ measurement result for the width and the fall of stepped-type ground fissure was collected to examine its development regularity (Table 3 ). It is observed that an evident characteristic of stepped-type ground fissure is that the fall is relatively high although the width is small. With respect to the fall, its development stage is divided into the rapid growth stage and stable growth stage. The fall increases sharply when the spatial position of stepped-type ground fissure is approximately directly above the 
Table 3 Relationship between the stepped-type ground fissure spatial position and working face advancing progress.

\begin{tabular}{ccccc}
\hline $\begin{array}{c}\text { Observation } \\
\text { time }\end{array}$ & $\begin{array}{c}\text { Advances in } \\
\text { working face } \\
(\mathrm{m})\end{array}$ & $\begin{array}{c}\text { Advancing distance } \\
\text { in working face } \\
(\mathrm{m})\end{array}$ & $\begin{array}{c}\text { Ground fissure } \\
\text { spatial position } \\
(\mathrm{m})\end{array}$ & $\begin{array}{c}\text { Ground fissure } \\
\text { advancing distance } \\
(\mathrm{m})\end{array}$ \\
\hline 2015.8 .19 & 390 & & 409.7 & 19.7 \\
2015.9 .2 & 430.8 & 40.8 & 448.6 & 17.8 \\
2015.9 .18 & 480.5 & 49.7 & 498.5 & 21.2 \\
2015.10 .7 & 540 & 59.5 & 561.2 & 20.5 \\
2015.10 .18 & 572 & 32 & 592.5 & 16.7 \\
2015.10 .25 & 590 & 18 & 606.7 & 24 \\
2015.11 .2 & 617 & 27 & 641 & \\
\hline
\end{tabular}

(a)

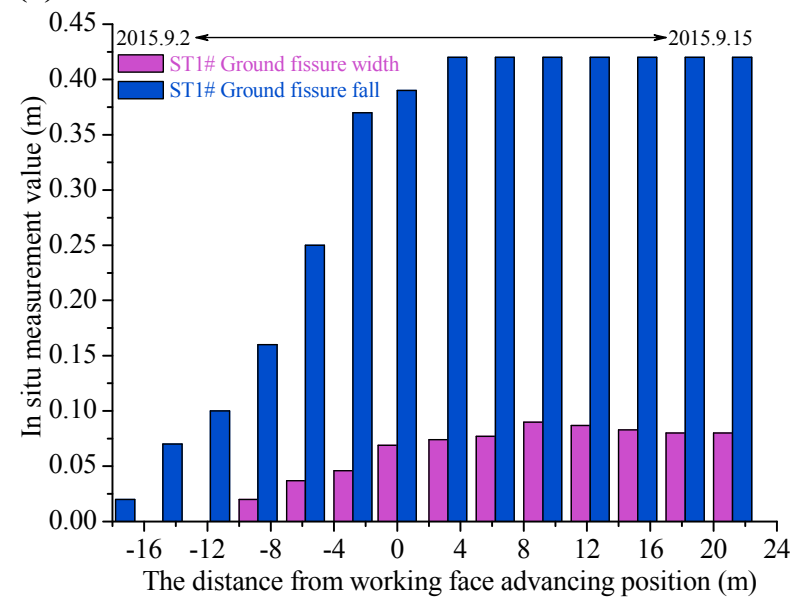

(b)

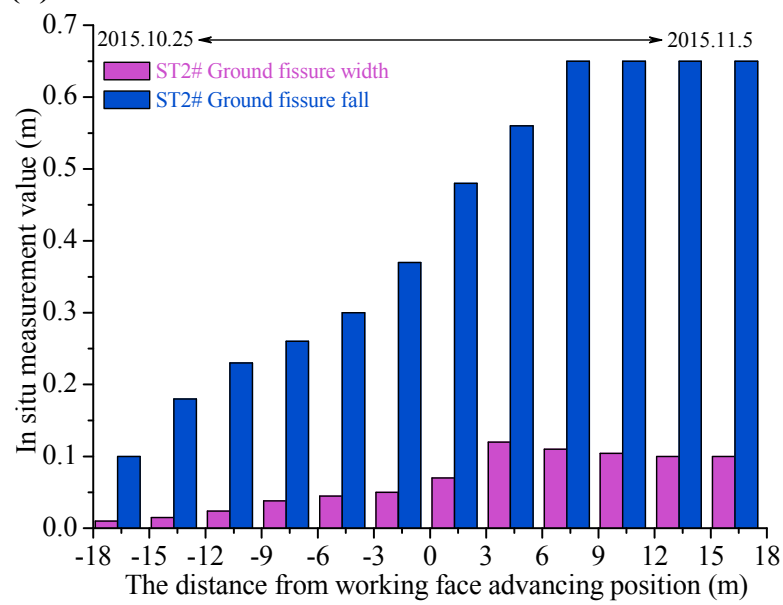

(c)

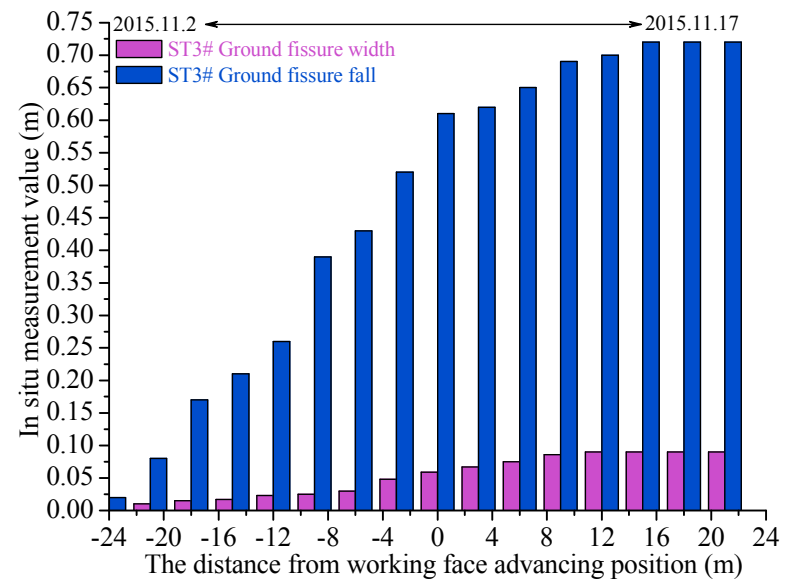

Fig. 6 Dynamic development of the width and fall for (a) ST1\# stepped-type ground fissure, (b) ST2\# steppedtype ground fissure and (c) ST3\# stepped-type ground fissure (Note: the distance value is negative when ground fissure is ahead of the working face while it is positive when it falls behind the working face).

working face advancing position. Hence, the fall of ST1\# stepped-type ground fissure increases from $0.16 \mathrm{~m}$ to $0.39 \mathrm{~m}$ when its distance that is ahead of the working face is within $8.8 \mathrm{~m}$. With respect to the fall of the ST2\# stepped-type ground fissure, it increases from $0.3 \mathrm{~m}$ to $0.65 \mathrm{~m}$ when its distance from working face advancing position varies from $-4.7 \mathrm{~m}$ to $7.3 \mathrm{~m}$. With respect to the ST3\# stepped-type ground fissure, its fall increases gradually when the working face advances continuously. The fall achieves maximum values of $0.42 \mathrm{~m}, 0.65 \mathrm{~m}$, and $0.7 \mathrm{~m}$ when the distances that fall behind the working face advancing position are $3.2 \mathrm{~m}, 7.3 \mathrm{~m}$, and $12 \mathrm{~m}$, respectively. When compared with the fall, the width typically exhibits a small value that ranges from $0.08 \mathrm{~m}$ to $0.1 \mathrm{~m}$. The width of ST1\# stepped-type ground fissure first increases gradually, then decreases, and finally tends towards a stable value of $0.08 \mathrm{~m}$. Stepped-type 


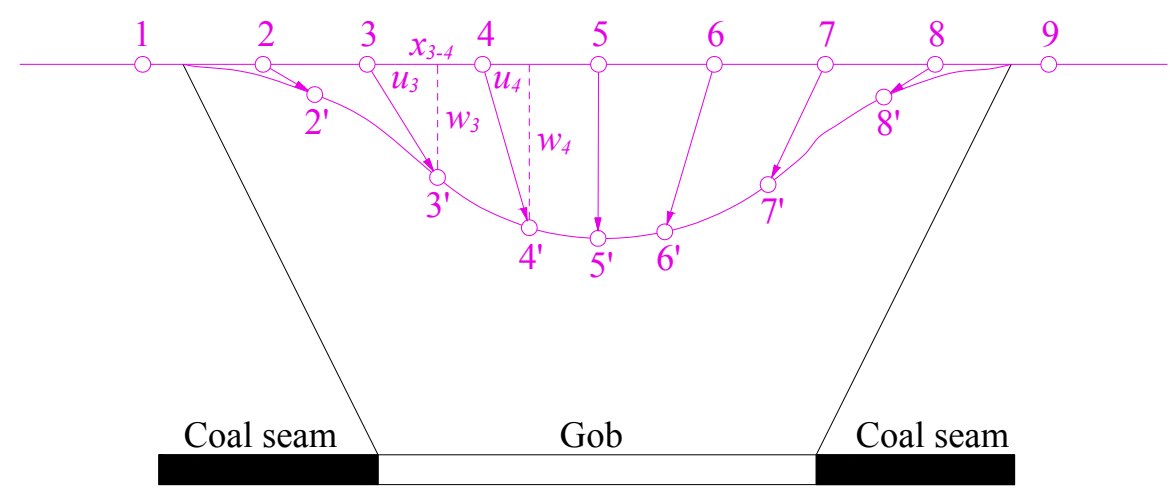

Fig. 7 Schematic diagram of the surface points movement.

ground fissures ST2\# and ST3\# also exhibit a similar regularity. A common feature of the width of steppedtype ground fissure is that the value tends towards stability when its spatial position falls behind the working face advancing position. The widths of stepped-type ground fissures ST1\#, ST2\#, and ST3\# reach a stable value of $0.08 \mathrm{~m}, 0.09 \mathrm{~m}$, and $0.1 \mathrm{~m}$, respectively, when the distances that fall behind the working face advancing position are $12.2 \mathrm{~m}, 10.3 \mathrm{~m}$ and $12 \mathrm{~m}$, respectively. It indirectly explains that the working face advancing progress significantly affects the development process of the width. With respect to the development cycle, it corresponds to $14 \mathrm{~d}, 12 \mathrm{~d}$, and $16 \mathrm{~d}$ with an average value of $14 \mathrm{~d}$. The working face advancing distance is $42 \mathrm{~m}$ within the time of $14 \mathrm{~d}$. The distance is equivalent to 1.9 times the periodic weighting step distance. It is observed that its development cycle is shorter than the development cycle of the sliding-type ground fissure.

\subsection{FORMATION MECHANISM OF MIGF}

The in situ stress of overlying strata and surface soil layer redistribute under the influence of mining activity. Given the differences in the lithology of overlying strata and surface soil layer, an inhomogeneous subsidence occurs. Existing studies indicated that formation process of MIGF is divided into two stages, namely the rock strata breakage stage and surface soil layer deformation stage (Wang et al., 2005). In the rock strata breakage stage, the roof gradually generates a bending deformation, and it breaks with the continuous expansion of the gob. The expansion area is sufficiently high, and thus rock strata deformation transfers to the ground surface. Fractures expand continuously from the bottom to the top along the vertical direction in rock strata. In the deformation stage of surface soil layer, the surface soil layer generates an inhomogeneous subsidence because of the topography fluctuation changes. Furthermore, when the loading exceeds its ultimate strength, the surface soil layer generates a discontinuous deformation along the extension direction of original fissures. The discontinuous deformation increases gradually, and thus the MIGF occurs under the coupled affection of roof strata deformation. Hence, MIGF is a specific embodiment of mining-induced deformation in two different media, namely the rock mass and soil body (Chen and $\mathrm{Hu}, 2018$ ). Hence, the formation mechanism of MIGF is examined from two viewpoints including surface subsidence and rock strata movement.

\subsubsection{SURFACE SUBSIDENCE AND MIGF}

The disproportion movement of different surface points significantly affects MIGF development (He et al., 1991). Figure 7 shows the horizontal movement and the vertical movement of two adjacent points on the ground surface. Given points 3 and 4 as an example, $u_{3}$ and $u_{4}$ refer to the horizontal movement while $w_{3}$ and $w_{4}$ represent the vertical movement. Horizontal movement difference $\Delta u=u_{4}-u_{3}$ and vertical movement difference $\Delta w=w_{4}-w_{3}$ refer to the width and fall of MIGF, respectively, which develops between points 3 and 4. Additionally, horizontal deformation $\mathcal{E}$ denotes the change of horizontal movement within a unit length as defined by the equation as follows:

$\varepsilon=\frac{u_{4}-u_{3}}{x_{3-4}}$

Where $\varepsilon$ denotes the horizontal deformation, $\mathrm{mm} / \mathrm{m} ; u_{3}$ and $u_{4}$ denote the horizontal movement of point 3 and 4 , respectively, $\mathrm{mm}$; and $x_{3-4}$ denotes the horizontal distance between points 3 and $4, \mathrm{~m}$.

Horizontal movement and horizontal deformation are two important factors that affect MIGF development. Previous studies indicated that horizontal deformation is extremely sensitive to the change in topography. The horizontal tensile deformation is typically generates in the mountainous slope while the horizontal compressive deformation occurs in the valley (Tang, 1989). A relatively large program was implemented to determine horizontal movement and horizontal deformation to understand the relationship between surface subsidence and MIGF. The situ measurement result of horizontal 
(a)

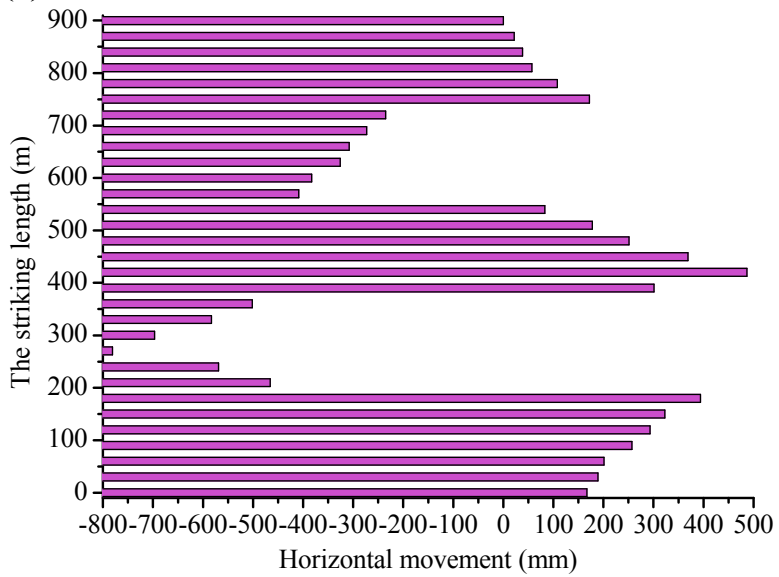

(b)

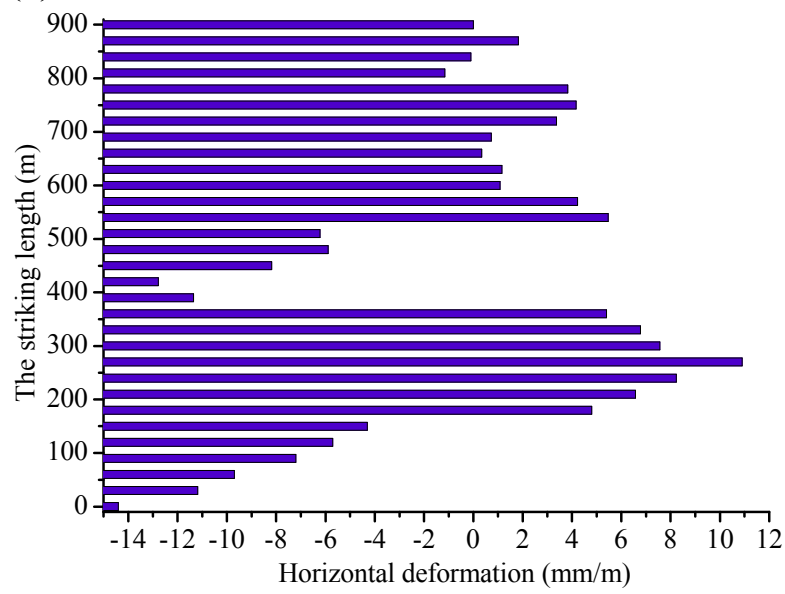

Fig. 8 (a) Horizontal movement changeable regularity along the striking direction and (b) horizontal deformation changeable regularity along the striking direction.

movement and horizontal deformation for monitoring point $\mathrm{Z} 1-\mathrm{Z} 31$ along the striking direction is shown in Figure 8 . In order to better examine the relationship between surface subsidence and MIGF, we conducted a sub-regional study based on the value of horizontal deformation and horizontal movement for monitoring points Z1-Z6, Z7-Z13, Z14-Z18, Z19-Z27, and Z28Z31.

1. Monitoring point of $\mathrm{Z} 1-\mathrm{Z} 6$

Measurement data revealed that horizontal movement value ranges from $167 \mathrm{~mm}$ to $323 \mathrm{~mm}$ while the horizontal deformation value varies from $-14.4 \mathrm{~mm} / \mathrm{m}$ to $-4.3 \mathrm{~mm} / \mathrm{m}$. It is known that the negative value of horizontal deformation indicates the compressive deformation while its positive value represents the tensile deformation (Gao, 1979). Based on measurement data for horizontal deformation, the coverage area of Z1-Z6 indicates a compressive state. Given the additional slippage of the valley, the horizontal movement value exhibits a positive value. The compressive deformation is unfavorable for MIGF formation. Based on the geological survey, few MIGFs are generated in the coverage area of Z1-Z6.

\section{Monitoring point of $\mathrm{Z} 7-\mathrm{Z} 13$}

In the coverage area of $Z 7-Z 13$, the horizontal movement increases continuously with a maximum value of $781 \mathrm{~mm}$. With respect to the horizontal deformation, it changes from negative to positive with an average value of $7.18 \mathrm{~mm} / \mathrm{m}$. This explains that horizontal deformation changes from the compressive state to the tensile state. The coverage area of Z7-Z13 belongs to the topography of mountainous slope due to the coupled affection of mining subsidence and additional slippage of mountainous slope, and the area is favorable for MIGF formation. After the field geological survey, seven sliding-type ground fissures were discovered in the area. The width changes from $0.17 \mathrm{~m}$ to $0.58 \mathrm{~m}$ while the fall varies from $0.78 \mathrm{~m}$ to $0.97 \mathrm{~m}$. Moreover, a landslide occurred in July 2015.

\section{Monitoring point of Z14-Z18}

Based on the topographic profile of the 9100 working face, it is known that the coverage area of Z14-Z18 lies in the valley. The maximum value of horizontal movement is $487 \mathrm{~mm}$ while the minimum value is $178 \mathrm{~mm}$. With respect to horizontal deformation, it changes from positive to negative with the value varies from $-5.89 \mathrm{~mm} / \mathrm{m}$ to $-12.78 \mathrm{~mm} / \mathrm{m}$. This explains that the area exhibits a compressive state. Hence, the condition is unfavorable for MIGF development. The conclusion is in agreement with the in situ observation result.

\section{Monitoring point of Z19-Z27}

The slope gradient increases gradually in the monitoring region of Z19-Z27 along the striking direction. It should be noted that the slope gradient changes significantly in two monitoring points of Z19 and Z20. Based on test data of horizontal deformation, its value ranges from $0.33 \mathrm{~mm} / \mathrm{m}$ to $5.47 \mathrm{~mm} / \mathrm{m}$, and thus it directly indicates the monitoring region shows a tensile state. The value of horizontal movement for monitoring points Z19, Z26, and Z27 is positive although it is negative for the other monitoring points. It explains that the region for monitoring points Z19, $\mathrm{Z} 26$ and $\mathrm{Z} 27$ is favorable for MIGF development. With respect to the field investigation, a sliding-type ground fissure is generated in the region near the monitoring point Z19 and four stepped-type ground fissures occur in the region of Z25-Z27.

\section{Monitoring point of Z28-Z31}

With respect to the monitoring region of $\mathrm{Z}_{2} 8$ $\mathrm{Z31}$, the maximum value of horizontal movement is $57 \mathrm{~mm}$ while the maximum value of horizontal deformation is $1.82 \mathrm{~mm} / \mathrm{m}$. Mining activity displays a small effect on surface subsidence. Thus there are only few tiny MIGFs in the region. MIGF is not observed based on field investigation result.

It is evident that horizontal tensile deformation easily occurs in the mountainous slope while 


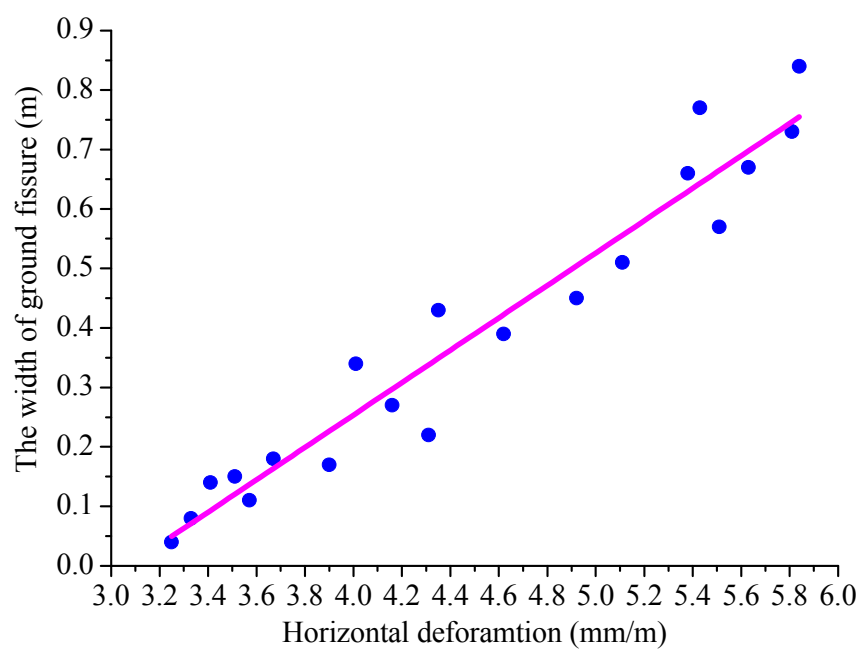

Fig. 9 Relationship between MIGF width and horizontal deformation.

horizontal compressive deformation generally occurs in the valley. Under the influence of horizontal tensile deformation, MIGF is typically generated in the mountainous slope or the region of slope gradient changes sharply. The conclusion is consistent with those obtained in previous studies (Wang et al., 2013).

Horizontal deformation significantly affects the development of MIGF width. A total of 20 measurement data were collected to understand the relationship between MIGF width and horizontal deformation. The width ranges from $0.04 \mathrm{~m}$ to $0.84 \mathrm{~m}$. With respect to horizontal deformation, the maximum value is $5.84 \mathrm{~mm} / \mathrm{m}$, and the minimum value is $3.25 \mathrm{~mm} / \mathrm{m}$. The relationship between MIGF width $(w)$ and horizontal deformation $(\varepsilon)$ is described by the equation $w=0.2723 \varepsilon-0.8357$; and the dependence is graphically expressed in Figure 9. The coefficient of determination for horizontal deformation is $\mathrm{R}^{2}=0.9377$. Thus, a positive relationship exists between MIGF width and horizontal deformation.

\subsubsection{ROCK STRATA MOVEMENT AND MIGF}

When compared with the northwestern area, roof strata movement exhibits its specific characteristic for broken feature and movement mode in southwestern area. Existing studies indicated that roof strata movement mode significantly affects the development regularity of MIGF (Ju and Xu, 2015; Wang et al., 2013). With respect to shallow burial coal seam of southwestern mountainous area, overlying strata tends to bend or collapse with main roof in the process of mining practice (Liu et al., 2012). Therefore, an examination of the main roof movement mode indicates the importance of formation mechanism of MIGF. The theory of mining pressure and strata control provides an important path to determine movement mode of main roof and development type of MIGF. The study is based on the theory.
The spatial position and thickness of the main roof affect its own breakage degree and movement mode although they also significantly affect the overlying strata movement and development regularity of MIGF. Thus, the determination of the spatial position of main roof is a key issue. Based on overlying strata property (obtained from lab tests), clay siltstone with the thickness of $6.6 \mathrm{~m}$ is determined as the main roof (Fig. 10).

In order to better understand the movement regularity of overlying strata, ten KBJ-60III-1 mining pressure monitoring instruments were arranged to record mining pressure with advances in the working face. The changeable regularity of the setting load and maximum support resistance for monitoring instruments $2 \#, 5 \#$ and $8 \#$ with respect to the monitoring time is shown in Figure 11. Specifically, monitoring instruments $2 \#$ and $8 \#$ were arranged near the ventilation roadway and haulage roadway, respectively, and monitoring instrument 5\# was arranged in the central region of the 9100 working face. The interval distance of the three monitoring instruments is $72 \mathrm{~m}$.

Monitoring data for setting load and support resistance were collected daily to reveal the overlying strata movement regularity as monitoring date. The monitoring time dates from 18 September till 20 October in 2015; and the working face advances from $485 \mathrm{~m}$ to $600 \mathrm{~m}$ with a progress of $115 \mathrm{~m}$ in the period. With respect to the topography, it changes from the valley to the mountainous slope (Fig. 4). Mining pressure characteristics of the 9100 working face are listed as follows: (1). When the working face advancing position lies in the valley, the periodic weighting step distance is relatively short with an average value of $12.1 \mathrm{~m}$ and the periodic weighting time is also relatively short. Field observations indicate that the main roof cuts directly along the rip and then causes a stepped-convergence. The support resistance increases sharply during this time. 


\begin{tabular}{|c|c|c|c|}
\hline--- & Lithology & Thickness (m) & Notes \\
\hline---- & & & Overlying strata \\
\hline - & Siltstone & 2.1 & \\
\hline & Sandstone & 4.8 & \\
\hline$=-$ & Claystone & 3.6 & \\
\hline & Gray sandstone & 9 & \\
\hline & Sandstone & 6.3 & \\
\hline 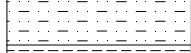 & Clay sandstone & 8.9 & \\
\hline - $-1--------1$ & Sandstone & 11.5 & \\
\hline & Fine sandstone & 8.8 & \\
\hline$\because \quad \therefore \quad \therefore 4$ & Siltstone & 5.5 & \\
\hline$-1+-$ & Clay siltstone & 6.6 & Main roof \\
\hline$----\cdots$ & Coal seam & 2 & Coal \\
\hline----- & Sandstone & 3 & Immediate floor \\
\hline----- & Siltstone & 3 & Main floor \\
\hline$-\cdots--$ & & & Underlying strata \\
\hline
\end{tabular}

Fig. 10 Generalized stratigraphy of the 9100 working face.

(a)

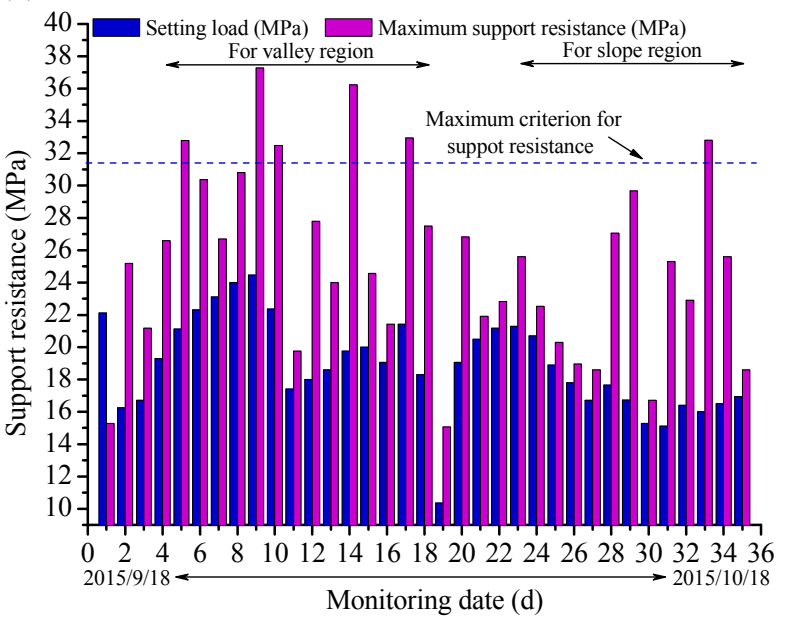

(b)

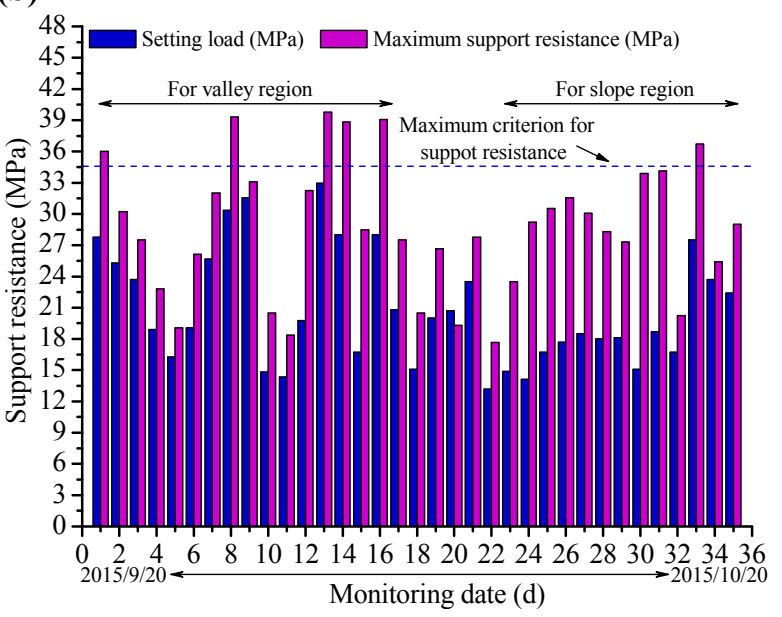

(c)

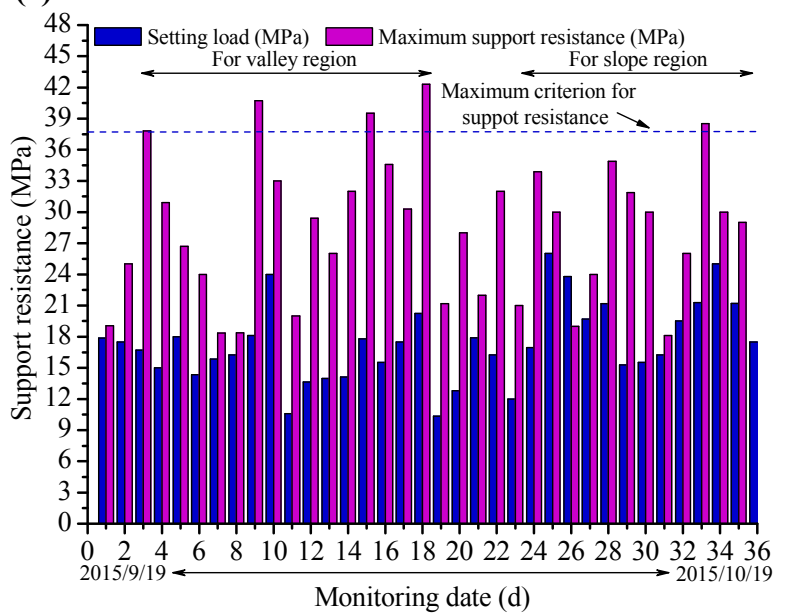

Fig. 11 Changeable regularity of the setting load and maximum support resistance with respect to monitoring time: (a) 2\# monitoring instrument; (b) 5\# monitoring instrument, and (c) $8 \#$ monitoring instrument. 


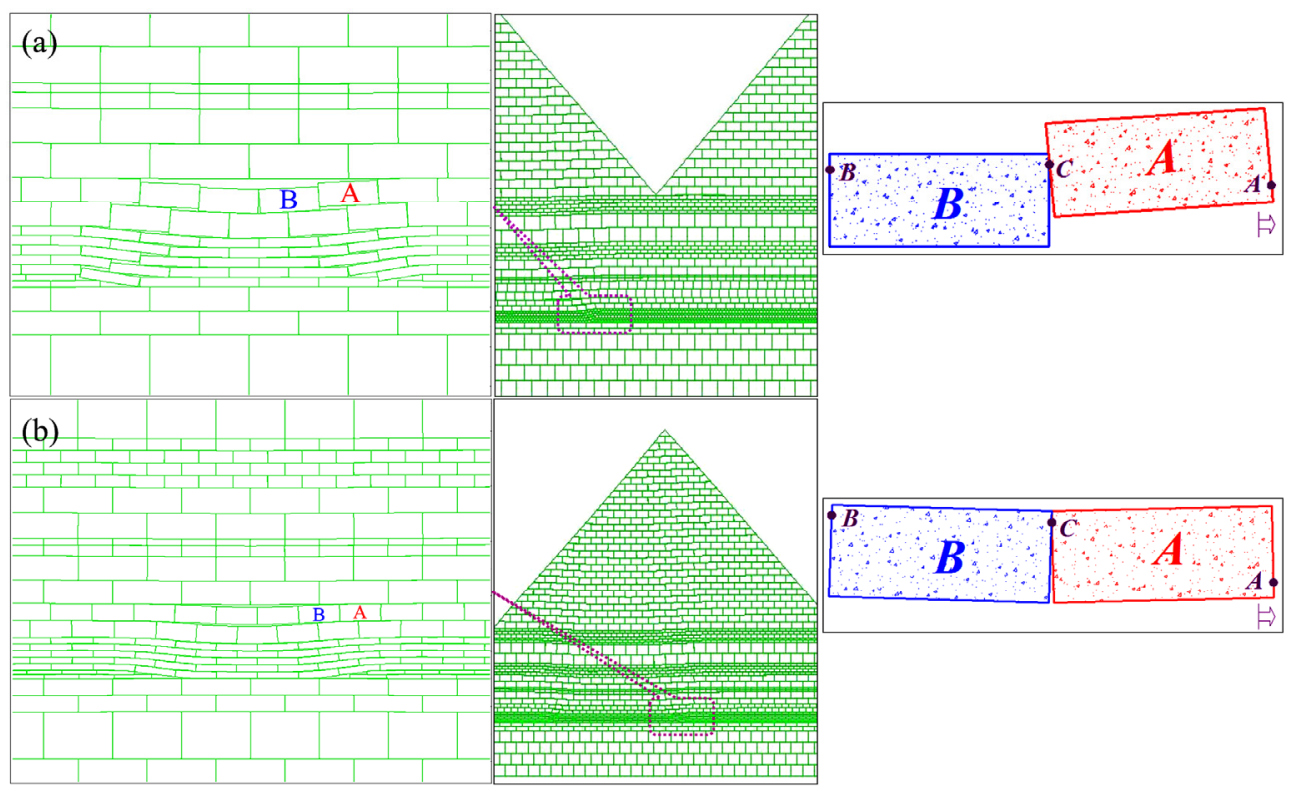

Fig. 12 Movement mode of the main roof: (a) stepped beam and (b) voussoir beam.

However, when the working face advancing position lies in the mountainous slope, the periodic weighting step distance increases and periodic weighting time also increases. Periodic weighting step distance is approximately $26 \mathrm{~m}$ while periodic weighting time is approximately $8 \mathrm{~d}$. (2) An in situ observation of the mining-induced ground surface indicates that several stepped-type ground fissures develop in the mountainous slope that is near the valley and a sinkhole occurs in the valley. This indicates that overlying strata movement directly affects surface subsidence. The changeable regularity of mining pressure suggests that overlying strata moves in different modes.

By using UDEC numerical simulation software, the main roof movement mode is shown in Figure 12. It is observed that main roof exhibits two different movement modes when the 9100 working face exhibits two different progressions. Hence, the main roof moves in a mode of "stepped beam" (Fig. 12(a)) when the topography for working face advancing position corresponds to the valley while main roof moves in a mode of "voussoir beam" (Fig. 12(b)) when the topography for working face advancing position corresponds to the mountainous slope. The main roof movement mode leads to different movement mode of overlying strata, and thus causes different formative types of MIGF. With respect to the former situation, rock block A and rock block B move in a mode of "stepped beam." Rock block B slides completely on the caved gangue while rock block A moves with advances in the working face. When satisfying the sliding condition, rock block A moves from the present state to the state of complete sliding likes rock block $\mathrm{B}$. With respect to the latter situation, rock block $A$ and rock block $B$ move in a mode of "voussoir beam." A hinged relationship exists between rock block $\mathrm{A}$ and rock block $\mathrm{B}$, and the rock block moves in the "rotating instability" state. The structural mechanical model of "stepped beam" and "voussoir beam" are shown in Figure 12. Rock block A and rock block B forms a structure of "stepped beam," and rock block A is supported by point A while rock block B is supported by point B. Rock block B slides with point $\mathrm{C}$. With respect to the structure of "voussoir beam", rock block A hinges on rock block B by point C. Given the coupled influence of topography and roof movement, there are two types of MIGF, namely stepped-type and sliding-type, as shown in Figure 13. It is observed that MIGF development type is significantly dependent on main roof movement mode. The "voussoir beam" movement mode of the main roof is favorable for the development of sliding-type ground fissures while the "stepped beam" movement mode of main roof leads to the development of stepped-type ground fissures.

\section{CONCLUSIONS}

The study was conducted in Anshun colliery, Guizhou Province, southwestern China with the aim of investigating the development regularity and formation mechanism of MIGF based on in situ measurement, geological surveys, theoretical analysis, and numerical simulation. The following three original aspects are included:

1. Sliding-type ground fissure and stepped-type ground fissure are the two typical types of shallow burial coal seams in the mountainous area. Sliding-type ground fissures generally occur in the mountainous slope with a large gradient while stepped-type ground fissures typically develop in the mountainous slope with a small gradient especially near the valley. Sliding-type 


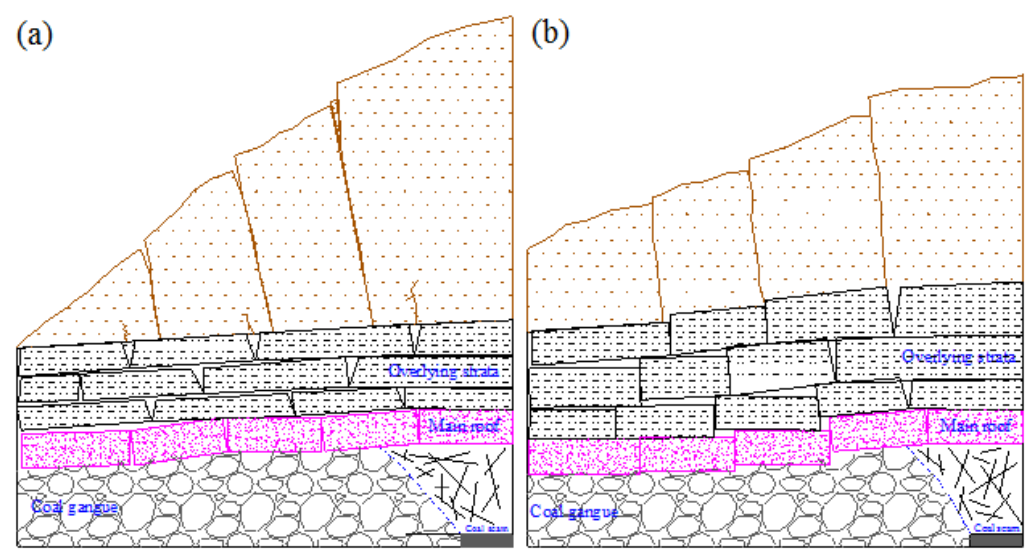

Fig. 13 Schematic diagram of the MIGF: (a) sliding-type ground fissure and (b) stepped-type ground fissure.

ground fissures exhibit a relative large width and fall. However, stepped-type ground fissures exhibit a relative small width and fall, and the average width is $0.14 \mathrm{~m}$ while the average fall is $0.39 \mathrm{~m}$.

2. A relative systemic program of in situ measurement was conducted to determine dynamic development regularity and development cycle of MIGF. A close relationship exists between MIGF dynamic development process and roof periodic movement. The advancing distance of a sliding-type ground fissure is 1.35 times periodic weighting step distance while it corresponds to 0.89 times periodic weighting step distance for a stepped-type ground fissure. Furthermore, the width and fall of the MIGF changes dynamically with advances in the working face. With respect to sliding-type ground fissure, the width and fall increases sharply when working face is directly under its spatial position. With respect to stepped-type ground fissure, the width and fall gradually increase when the working face advances. The development cycle of a sliding-type ground fissure is $18.3 \mathrm{~d}$ while it corresponds to $14 \mathrm{~d}$ for a stepped-type ground fissure.

3. Horizontal tensile deformation is favorable for MIGF development, and a positive relationship exists between horizontal deformation and MIGF width. The main roof movement mode significantly affects the development type of MIGF. The "voussoir beam" movement mode of the main roof is favorable for the development of sliding-type ground fissure development while the "stepped beam" movement mode of main roof leads to the development of stepped-type ground fissure.

\section{ACKNOWLEDGEMENTS}

This study was supported by the National Natural Science Foundation of China (51574243), the
Fundamental Research Funds for the Central Universities of China (2010YZ02) and Yue Qi Distinguished Scholar Project (800015Z1138). The author also thanks other researchers for their valuable suggestion and constructive assistance.

\section{REFERENCES}

Adibee, N., Osanloo, M. and Rahmanpour, M.: 2013, Adverse effects of coal mine waste dumps on the environment and their management. Environ. Earth Sci., 70, 1581-1592.

DOI: $10.1007 / \mathrm{s} 12665-013-2243-0$

Bell, F.G. and Genske, D.D.: 2001, The influence of subsidence attributable to coal mining on the environment, development and restoration: some examples from Western Europe and South Africa. Environ. Eng. Geosci., 7, 81-99. DOI: $10.2113 /$ gseegeosci.7.1.81

Chen, C. and $\mathrm{Hu}, \mathrm{Z} .:$ 2018, Research advances in formation mechanism of ground crack due to coal mining subsidence in China J. China Coal Soc., 43, 810-823. DOI: $10.13225 /$ j.cnki.jccs.2017.0942

Commission NE: 2016, The 13th Five-Years Plan for Economic and Social Development of China (20162020). Beijing.

Fan, L., Zhang, X., Xiang, M., Zhang, H., Shen, T. and Lin, P.: 2015, Characteristics of ground fissure development in high intensity mining area of shallow seam in Yushenfu coal field. J. China Coal Soc., 40, 1442-1447. DOI: 10.13225/j.cnki.jccs.2014.1707

Gao, L.: 1979, Mining rock mechanics. Metallurgical industry press.

Han, K., Kang, J., Wang, Z. and Wu, K.: 2014, Prediction of surface fissure in high relief areas induced by underground coal mining. J. Min. Saf. Eng., 31, 896900. DOI: 10.13545/j.issn1673-3363.2014.06.011

He, G., Yang, L., Ling, G., Jia, F. and Hong, D.: 1991, Mine mining sudsidence. China University of Mining and Technology press.

Hu, Z., Wang, X. and He, A.: 2014, Distribution characteristic and development rules of ground fissures due to coal mining in windy and sandy region. J. China Coal Soc., 39, 11-18.

DOI: $10.13225 /$ j.cnki.jccs.2013.1289 
Huang, Y., Tian, F., Wang, Y., Wang, M. and Hu, Z.: 2014, Effect of coal mining on vegetation disturbance and associated carbon loss. Environ. Earth Sci., 73, 23292342. DOI: $10.1007 / \mathrm{s} 12665-014-3584-\mathrm{Z}$

$\mathrm{Ju}, \mathrm{J}$. and $\mathrm{Xu}, \mathrm{J} .:$ 2015, Surface stepped subsidence related to top-coal caving longwall mining of extremely thick coal seam under shallow cover Int. J. Rock Mech. Min. Sci., 78, 27-35.

DOI: $10.1016 /$ j.ijrmms.2015.05.003

Li, J. and Liu, C.: 2017, Formation mechanism and reduction technology of mining-induced fissures in shallow thick coal seam mining. Shock Vib., 6, 1-14. DOI: $10.1155 / 2017 / 1980817$

Li, L., Wu, K., Hu, Z., Xu, Y. and Zhou, D.: 2017, Analysis of developmental features and causes of the ground cracks induced by oversized working face mining in an aeolian sand area. Environ. Earth Sci., 76, 1-12. DOI: $10.1007 / \mathrm{s} 12665-017-6452-9$

Liu, G., Fan, K. and Xiao, T.: 2012, Research on working resistance of mining working face in mountainous buried coal seam. Chin. J. Undergr. Space Eng., 8, 1034-1040.

Liu, H., Deng, K., Lei, S., Bian, Z. and Chen, D.: 2017, Dynamic developing law and governance standard of ground fissures caused by underground mining. J. Min. Saf. Eng., 34, 884-890. DOI: 10.13545/j.cnki.jmse.2017.05.009

Liu, H., Liu, X., Deng, K., Lei, S. and Bian, Z.: 2016, Developing law of sliding ground fissures based on numerical simulation using UDEC. J. China Coal Soc., 41, 625-632. DOI: $10.132255 /$ j.cnki.jccs.2015.0454

Malinowska, A.A.: 2016, The impact of deep underground coal mining on Earth fissure occurrence. Acta Geodyn. Geomater., 13, 321-330. DOI: 10.13168/agg.2016.0014

Marschalko, M., Bednarik, M., Yilmaz, I., Bouchal, T. and Kubecka, K.: 2012, Evaluation of subsidence due to underground coal mining: an example from the Czech Republic. B. Eng. Geol. Environ., 71, 105-111. DOI: $10.1007 / \mathrm{s} 10064-011-0401-8$

Qiao, J.: 2000, On the preimages of parabolic periodic points. Nonlinearity, 13, 813-818. DOI: $10.1088 / 0951-7715 / 13 / 3 / 316$

Shi, W., Huang, R., Zhao, J., Ju, N. and Xiang, X.: 2016, Genetic mechanism of mining cracks of gently inclined slope in mountains. Eng. Geol., 24, 768-774. DOI: 10.13544/j.cnki.jeg.2016.05.006
Tang, F.: 1989, Analysis of mining-induced landslide mechanism. J. Xi'an Min. Inst., 5.

Wang, J., Lv. Y., Liu, H. and Kang, J.: 2005, Distribute characteristic and formation mechanism of mininginduced ground fissure in Xiqu coal mine. Shanxi Coal, 25.

Wang, X.-f., Zhang, D.-s., Zhang, C.-g. and Fan, G.-w.: 2013, Mechanism of mining-induced slope movement for gullies overlaying shallow coal seams. J. Mt. Sci., 10, 388-397. DOI: 10.1007/s11629-013-2455-5

Xu, N., Gao, C., Ni, X. and Liu, M.: 2015, Study on surface cracks law of fully-mechanized top coal caving mining in shallow buired depth and extra thick seam. Int. J. Coal Sci. Technol., 43, 124-128.

$\mathrm{Xu}, \mathrm{Y} ., \mathrm{Wu}, \mathrm{K}$. , Bai, Z. and Hu, Z.: 2017, Theoretical analysis of the secondary development of mininginduced surface cracks in the Ordos. Environ. Earth Sci., 76, 703. DOI: 10.1007/s12665-017-7050-6

Zhang, C., Mitra, R., Oh, J. and Hebblewhite, B.: 2015, Analysis of mining-induced valley closure movements. Rock Mech. Rock Eng., 49, 1923-1941. DOI: 10.1007/s00603-015-0880-1

Zhao, K., Xu, N., Mei, G. and Tian, H.: 2016, Predicting the distribution of ground fissures and water-conducted fissures induced by coal mining: a case study. SpringerPlus, 5, 997. DOI: 10.1186/s40064-016-2609-3

Zhu, H., He, F., Zhang, S. and Yang, Z.: 2018, An integrated treatment technology for ground fissures of shallow coal seam mining in the mountainous area of southwestern China: a typical case study. Gospodarka Surowcami Mineralnymi-Mineral Resources Management, 34, 119-138. DOI: $10.24425 / 118641$

Zhu, H., Liu, P., Chen, P. and Kang, J.: 2017, Analysis of coalbed methane occurrence in Shuicheng Coalfield, southwestern China. J. Nat. Gas. Sci. Eng., 47, 140153. DOI: $10.1016 /$ j.jngse.2017.09.003 